\title{
ANALYSIS ON EARLY CHILDHOOD SEXUAL ABUSE AND THE IMPLICATIONS IN ISLAMIC EDUCATION
}

\author{
Erhamwilda \\ Early Childhood Education, Tarbiyah dan Education Faculty, Islamic University \\ Bandung (UNISBA), Indonesia \\ Jl. Tamansari No. 1, West Java 40116 \\ Email: erham_wilda@yahoo.co.id

\section{Nurul Afrianti} \\ Early Childhood Education, Tarbiyah dan Education Faculty, Islamic University \\ Bandung (UNISBA), Indonesia \\ Jl. Tamansari No. 1, West Java 40116 \\ Email: nurulafrianti@yahoo.com
}

\begin{abstract}
Fulfillment of children's rights has been a concern of Indonesia stated in the ratification of the Convention on the Rights of the Child and Act No. 23 of 2002 on Child Protection. However, violence against children is increasing each year. The most dominant violence emerged in recent years is sexual abuse committed against children aged 5 to 11 years, and the perpetrators of sexual abuse are close with the children. Concern about cases of sexual abuse in early childhood and their impact, should be followed by an effort to develop a variety of approaches and methods of sex education in accordance with religious and cultural values in which children live.
\end{abstract}

Keyword: Sexual Abuse, Child

\begin{abstract}
ABSTRAK
Pemenuban terhadap hak anak telah menjadi perhatian bangsa Indonesia yang tercantum dalam ratifikasi Konvensi Hak Anak serta Undang-undang Nomor 23 Tabun 2002 tentang Perlindungan Anak. Namun demikian, tindak kekerasan terbadap anak setiap tabun semakin meningkat. Tindak kekerasan yang paling dominan muncul pada akhir-akbir ini adalab tindak. kekerasan dan pelecehan seksual (sexual abuse) yang dilakukan terhadap anak berusia sekitar 5 hingga 11 tabun, dan yang paling menyedibkan pelaku kekerasan dan pelecehan adalah orang dekat. Keprihatinan terbadap kasus kekerasan dan pelecehan seksual pada anak usia dini dan dampaknya, perlu diikuti dengan upaya mengembangkan berbagai pendekatan dan metode pendidikan seks yang sesuai dengan nilai religius dan budaya di mana anak hidup. Tindakan yang sifatnya preventif, promotif disamping upaya-upaya yang sifatnya treatment bagi anak yang menjadi korban kekerasan seksual, perlu terumuskan secara kongrit.
\end{abstract}

Kata Kunci: Kekerasan Seksual, Anak 


\section{INTRODUCTION}

Indonesia has ratified the Child Rights Convention since 5 September 1990. Indonesia has a commitment to respect and fulfill the rights of children, which is in principle already contained in the Act of 1945 Article 28 B (2). Furthermore, for operational regulated Act No. 23 of 2002 on Child Protection. With reference to the right of the child, its has been properly for optimal growth and development as well as protection from various forms of violence to the attention of all parties. While the facts today show there is still a lot of children are not able to grow flowers properly, treated unreasonably, ignored, not even a little bit that gets physical violence, psychological, and sexual.

News reports about child abuse through print, electronic and online often quite sad to be heard or watched. Children abandoned by parents, children malnutrition, children are employed, and children become victims of sexual violence from the nearest even from people who are supposed to protect, cherish and meet the needs of children to grow and develop optimally.

Sexual abuse is one of the thousands of cases that occurred in Indonesia. The report of the National Commission for Child Protection (Komnas PA) during the year 2013 there have been more than three thousand (3023) cases of violence against children. Of these, 58\% (1753) is a case of sexual abuse in children. While in the first four months of 2014, cases of child abuse has occurred up to 239 cases and $42 \%$ (100) is sexual abuse. Children are extremely vulnerable to all forms of violence including sexual abuse. In fact, research conducted Krug (2002, p. 10-15) asserts that children at greatest risk of abuse (violence) and the girls at greatest risk of sexual abuse (Erhamwilda, 2015, p. 197).

Sexual Abuse: Generally defined as contacts between a child and an adult or other person Significantly older or in a position of power or control over the child, where the child is being used for sexual stimulation of the adult or other person "(Committee on Professional Practice and Standards, APA Board Of Professional Affairs. The American Psychologist 54 (8): 58693 August 1999).

Sexual abuse of children is a form of child abuse in which an adult or older adolescent uses a child for sexual stimulation (Mildline Plus 2008 US National Library of Medicine). Sexual abuse of children is the involve a child in any form of sexual activity that occurred before the child reaches the age limit imposed by the law of the country concerned where an adult or another child who is older or who are considered to have more knowledge of the children use it for pleasure sex or sexual activity. (CASAT programe, Child Development Institute; Boyscouts of America; Komnas PA) Lyness. 
Most victims of sexual abuse in children aged 5 to 11 years. For offenders, sex does not affect the sexual assault is important for perpetrators of sexual desire they can be channeled. Actors in the mode of approaching the victim is varied for example they live closer to the victims and chatting course, persuade victims, there are also some that seduce and coerce the victim (Doni \& Mira, 2010, p. 1).

Maslihah (2013, p. 22) quotes from a variety of research on the impact of sexual abuse on children include: feelings of guilt and self-blame, the shadow of events in which children receive sexual violence, nightmares, insomnia, fear of things associated with abuse (including objects, smells, places, visit doctors, etc.), self-esteem problems, sexual dysfunction, chronic pain, addiction, suicidal ideation injury, suicide, somatic complaints, depression (Roosa, Reinholtz., Angelini, 1999, 66-70). Besides appearing disorders such psychological post-traumatic stress disorder, anxiety, other mental illnesses (including personality disorder and dissociative identity disorder, a tendency to re-victimization in adulthood, bulimia nervosa, physical injury to the child (Levitan, Rector, Sheldon, \& Goering, 2003; Messman-Moore, Terri Patricia, 2000; Dinwiddie, Heath, Dunne, Bucholz, Madden, Slutske, Bierut, Statham et al, 2000, p. 35-36). Sexual abuse that afflicts mainly children and women, causing problems later in life, such as eating disorders (anorexia or bulimia), sexual problems, abuse yourself and suicide, somatic symptoms, anxiety, destruction of self-esteem, or prolonged depression (Illenia \& Handadari, 2011; Knauer, 2002; p. 119).

Concern over cases of sexual abuse in early childhood and their impact, should be followed by an effort to develop a variety of approaches and methods of sex education in accordance with religious and cultural values in which children live. Actions that are preventive, promotive addition to the efforts of its treatment for children who are victims of sexual violence, should be formulated kongrit.

Currently the experts of psychology and psychiatry have developed various methods and therapeutic techniques for the recovery of victims of sexual violence, but far more important is to develop approaches and methods of sex education for early childhood with the development of the child and does not violate the values and norms of the religious affiliations children and their families.

In preventing early childhood of sexual abuse, still needs to be researched and understood the phenomenon of sexual abuse in early childhood comprehensive manner, both in terms of victims, perpetrators, and environmental life. An understanding of cases of sexual violence by empirical can be the basis for the development of approaches and methods of sex education for young children can be continuous and sustainable, and 
fit today's challenges. Therefore this study was conducted to answer the formulation of the following problems: (1). How personal characteristics, the neighborhood children who become victims, the relationship between children and parents, and the incidence of sexual assault on a child ?; (2) What actions do parents after the incident ?; (3) How do the characteristics of the offender and the environment ?; (4) how the educational implications of cases of sexual violence?

\section{Sexual Abuse}

At the beginning, the term child abuse or child abuse and neglect is known from the world of medicine. Around 1946, Caffey-a radiologist reported cases of injury in the form of clinical symptoms such as long bone fracture plural (multiple fractures) in children or infants with subdural bleeding without knowing why (Unrecognized trauma). In medicine, this term is known as Caffey Syndrome.

Lyness (Maslihah, 2006, p. 27) sexual abuse of children include the act of touching or kissing a child's sexual organs, sexual acts or rape of a child, exposing the media / object porn, showing genitals in children and so on. Sexual abuse of children is a form of child abuse in which an adult or offenses committed by older adolescents of a child to obtain sexual stimulation. According Supardi and Sadarjoen (Illenia \& Handadari, 2011, p. 121) sexual abuse is any form of behavior that has sexual content carried by someone or some people but not favored and is not expected by the people who were targeted, giving rise to negative consequences such as shame, offended, insulted, loss of self-esteem, and loss of purity. Sexual violence includes measures forcing sexual intercourse until the non-physical contact, such as sexual scenes displaying or exposing genitals.

Sexual abuse includes activities by a parent or caretaker such as fondling a child's genitals, penetration, incest, rape, sodomy, indecent expose, and exploitation through prostitution or the production of pornographic materials (Dacey and Fiore, 2006, p. 94-95). That is the action that is classified to sexual violence include the activities carried out by a parent or caregiver such as fondling a child's genitals, penetration, incest, rape, sodomy, exposing indecent acts, and exploitation through prostitution or the production of pornography.

Sexsual abuse of children is a tragic problem affecting children of all ages and from all walks of life. It is not widespread, but it happens Often enough to be a cause for great concern. Some children are abused by strangers, but that is rare. More Often they are abused by someone they know and trust: a relative, friend, neighbor, coach, baby-sitter, scout leader, parent, or cleric. Sexual abuse is not usually a violent act. The child is 
Involved in "games" ar seduction over a period of time (Dacey and Fiore, 2006, p. 95).

Sexsual child violence is a tragic problem that affects children of all ages and from all walks of life. It is not much, but it happens and very alarming. Some children are abused by strangers, but only a small part. Sexual violence is more often committed by someone known and trusted, such as; relatives, friends, neighbors, coaches, baby-sitter, scout leaders, parents, pastors or religious leaders. Sexual violence is often not considered to be acts of violence, because the child was involved in the "game" or seduced during a specific time period.

\section{Category of Sexual Abuse}

Based on the identity of the offender can be divided into two categories:

1. Familial Abuse

Including familial abuse is incest, ie sexual assault where the victim and the perpetrator is still in the blood relationships, be part of the nuclear family. In this case include a person who becomes a substitute parent. Mayer (Tower, 2002) mentions the category of incest in families and linking with child abuse. The first category, sexual molestation (persecution). This includes interaction noncoitus, petting, fondling/ caressing/ flattery, exhibitionism, and voyeurism/ A people's business interference, all matters relating to stimulate sexual offenders. The second category, sexual assault (rape), in the form of oral or relationship with the genitals, masturbation, fellatio (oral stimulation of the penis) and cunnilingus (oral stimulation of the clitoris). The most fatal last category is called Forcible rape (forcible rape), including sexual contact, fear, violence, and threats that the victim experiencing difficulties. Mayer said that at most the last two categories heaviest traumatic for children, although the victim does not say just as it is.

2. Extrafamilial Abuse

According to Hall (Maslihah, 2013, p. 25), approximately 95\% of incidents of sexual abuse of children aged 12 and younger committed by offenders who have deviations in the form of pedophilia, and these people become $65 \%$ of perpetrators of child abuse. Pedophiles, child molesters commit sexual acts against children, ten times more than a child molester nonpedofil.

Pedophilia is derived from the Greek language meaning paides childhood. Pedophilia have strong sexual urges or fantasies through sexual intercourse with a child. Sexual abuse on a child's behavior be exhibited sexual organs (exhibitionism), oral sex, sexual intercourse through the anus, sexual intercourse and touching the opposite sex Ongan-sexual organs. 
Touching parts sensistif a behavior that most often occur in the perpetrators of sexual abuse in children.

Perpetrators pedophila are those aged at least 16 years old and of different ages, at least 5 years with the victim, but that the victim is a child of his own family (incest), stepbrother or even other children that there is no family relationship with the perpetrator. Most of the victims are female childhood, but there are also victims boy.

A survey in the United States in 2006 turned out to be $27 \%$ adult women victims of sexual abuse when the child - a child, while $16 \%$ are victims of childhood male. Moreover Herman \& Hirschman, 1981; Zevrina, et al, 1987 (Salter, 1988, p. 42) reported between 20\%-30\% of adult women sexually abused in childhood are carried out by strangers, family and friends. Most of the perpetrators are also victims when they were a child.

American study also found that of the 229 victims of sexual abuse $25 \%$ are children under the age of 6 years, $25 \%$ of children between the ages of 6 10 years and $50 \%$ of adolescents aged $11-13$ years, touching the organ sensitive to the most common, followed by sexual intercourse and intercourse oral sex. They do so by persuasion and seduction (Erickson, Walbek \& Seely, 1988; Mc Anuity \& M.Michele, 2006). In 2002, based on extensive national study in the United States almost 900,000 children in America who are victims of violence or ignored, or 12 out of 1,000 children. Approximately $60 \%$ of children victims of neglect by parents or caregivers, nearly 20\% received physical violence, and 10\% were sexual abuse and emotional maltreatment rest (Dacey and Fiore, 2006, p. 95).

In Indonesia, child sexual assault cases synonymous with rape, including incest, yet very little is revealed. Among the many cases of incest that occurs is the father of rape cases in children who are still minors, brother and sister, between mother and child even his own (Setiawan, 2014, p. 1).

Further Setyawan suggested that incest had not deter the perpetrators, because of legal action is not always a death sentence, a maximum of only 15 years in prison, while in other countries have a lot to apply the death penalty. The act of rape or sexual crimes have generally experienced by women who were children or adolescents and in general, the perpetrator and the victim came from low social stratification. Sexual violence can occur due to environmental factors and psychological background of the offender in the past as a form of mental unpreparedness, which then influence the behavior of perpetrators of sexual violence spontaneously due to the stimulation. 


\section{Preventive Efforts Sexual Abuse in Children}

Prevention of Sexual Abuse in Children

This time through online media has been expressed a number of tips that parents can do to prevent children from becoming victims of sexual violence, although in certain cases still to be scrutinized, especially of the order of religious and socio-cultural values adopted by the people of Indonesia. Some tips are as follows.

1. Do not give clothing that is too open because it can be a stimulus for sexual harassment;

2. Embed shyness early and teach your child not to be undressing in the open, nor urinate than in the bathroom;

3. Keep your children from pornography either the film or advertising;

4. Know with whom the child spends time and accompany it while playing with his friends. If it is not possible then frequently monitor their condition on a regular basis;

5. Do not allow children to spend time in remote places with other adults or boys older;

6. If using a nanny, babysitter plan to visit you without prior notice;

7. Tell children not to talk or receive gifts from strangers;

8. Encourage your child if he refuses hugged or kissed someone (although still family), you can explain to those concerned that your child is not in the mood. That way your child learns that he has authority over his own body;

9. Listen when your child trying to tell you something, especially when it looks difficult to convey it;

10. Give your child enough time so that the child will not seek attention from other adults.

For older children:

1. Teach the use of a secure internet - give him a time limit in using the internet, always keep an eye on the sites that it is open. Explain that not everyone he knew on the Internet as well as he thought, so he should not be carelessly tell their story;

2. Ask the children to immediately inform you if there is a message or image that makes the child uncomfortable;

3. Keep an eye also use gadgets such as cell phones or smartphones not to expose the child porn case through such tools although it is not accidental because it can affect the sexual development of children;

4. Give pendidikasn sex as early as possible (from the age of 2 or 3 years);

5. Teach children 2-3 years to clear take a leak and take a dumb itself an indirect way to teach children keep the privacy of his body; 
6. For children 3-5 years old, teach about the privacy of body parts of a personal nature, which should only be touched by himself, mothers, and others with the permission / mother's presence;

7. For children aged 5-8 years give false sense of touch to avoid that touch on the body of children's privacy, and the right touch and are allowed to shake hands and kiss while saying goodbye or home school;

8. Be a shelter for your child and do a short talk from time to time. (www.bayiku.org)

National Commission for Protection of Indonesian Children (KPAI) has also devised a kind of Tips "Mitigation of Social Anti Sexual Violence on Children" which features a picture that contains a message about what to do child if there are people who will hold the privacy of his body, then introduce children part of his body, his privacy that should not be held arbitrarily by others without the knowledge of her mother.

\section{Factors Causing Sexual Abuse}

Experts in the field of sexual crimes against children stated that sexual activity in minors always raises two possible triggers: experience and see. This means that children who are sexually deviant often see sex scenes with no scientific explanation which always arouse lust and lead to addiction. (Andika, 2010, p. 31). Results of the study Dr. Jennings Bryant (Andika, 2010, p. 32) showed 600 teenagers both men and women in the United States, $91 \%$ of men and $82 \%$ of women admitted to watching porn or that contain sexual violence. More than $66 \%$ of men and $40 \%$ of women reported wanting to try some sex scenes that have been seen. Among the junior high school students, $31 \%$ of men and $18 \%$ of women admitted to actually do some scenes in the porn film was a few days after watching it.

\section{Sex Education For Young Children}

A culture that sees children talking about sex is taboo, can lead to lack of child acquire the right knowledge and good about sex or children looking for their own answers about sex in the wrong way. Understanding parents about the child's psychosexual development stage is important as a basis in determining the strategy of communication of sex education to children.

Referring to Freud psychoanalytic theory, the early childhood (ages 0-6 years) is in Phase pragential where children are not aware of the functions and differences in the male genitals to women. This phase consists of the oral stage ( $0-2$ years) and the anal stage ( $2-4$ years). Oral phase marked by children enjoy the fun with the mother's nipple sucking, this stage, children receive sexual information through the activity of his mouth and when age (1-2 years) enjoyed incorporate everything into his mouth. Children tend to enthusiastically enter anything seen in his mouth. Anal stage (2-4 years). 
Satisfaction child obtained through the anus area and pleasure felt children through the activity of the disposal process. Children tend to linger in the bathroom and not infrequently hold urination and defecation. Furthermore, at the age of 4-6 years old children are in the early phase of the Phallus where sex started to realize the difference between him and his friend of the opposite sex. When entered the age of 4 years, children will feel the pleasure when touched or touched her genitals. Children begin likes to compare his genitals with his friend, even the boys often hold or rub her genitals.

Kriswanto (2015, p. 1), psychologist Jagadnita Consulting, warned: "sex education for children should start early ie since the age of 0-5 years (toddlers). After the children aged over one year, can be done the following.

1. Encourage children to identify body parts, and explain the function of each part with simple language. Saying that the body is a precious gift and should be maintained properly.

2. Build a positive habit. For example, do not change clothes in the open, do not pee in any place, etc.

3. Plant the importance of maintaining a certain body organs, such as the genitals, from the touch of another person, with the simple explanation that can be understood dterima and children.

4. Familiarize children dress according to gender identity early on. Negligence in this regard can cause a child to experience identity confusion.

\section{Sex Education for Children Islamic Perspective}

One of the rules behave very considered in Islam is a moral association between men and women has been started at an early age. Islam teaches different ethical welcomed the birth of a baby boy with a woman, ranging from naming, aqiqah (slaughtered one sheep for girls and two sheep for a boy), then Islam teaches a different dress code for son boys with girls, and to distinguish male genitalia with women, all of whom began to be taught from an early age. Following that Islam teaches ethics ask for permission to enter the room of parents in three states (before the dawn prayer, the time of day when ordinary parents undress in the rest, and after evening prayers), as listed in the QS An-Nur: 58-59. When examined command requesting the permit contains the value of sex education, in which children are not prevented to see the nakedness of the parents, and not see if there is an intimate relationship of husband and wife. As noted Nashih Ulwan (1995, p. 165) that a command requesting the permit to keep the children not to see a parent in a sexual relationship, and then tell their friends. Children will be confusion when the event occurred to her, or whenever imagine the sights he had ever seen in the parents' room. 
Another important ethics taught in Islam is growing and shame. Shame is one of emotional intelligence, in order to cover the person's body is not worth seeing by careless people. The growth of shame became the forerunner to memprotek children so that others do not see much less holding and misbehave with his cock. Furthermore, Islam teaches restrictions genitalia may be seen and should not be viewed as per the age of a person's development. For the children of men and women under the age of 4 years has not been required to close the genitals, but accustom small children close the genitals is more mainstream. For children over 4 years of age are kubul private parts (genitals), anal, and surrounding areas. Islam also regulates the relationship between men with women, men with men, and girls with girls, which is not allowed to see their genitals. The increasing age of the child will be more strict rules to keep the honor of the child, to be treated well, and did not deviate sexual development.

Islam teaches sex education to teach ethics to see, because seeing is the root of the turmoil lust. Almost all sexual perversion begins from seeing partner/ object quieting sex, sex scenes directly or indirectly seen through the spectacle, news, reading, poster-images, or the site on line. Furthermore, Islam puts the responsibility of sex education in the elderly with tertama prevent children from sexual stimuli by running two responsibilities are: oversight responsibility of internal factors and external factors oversight responsibility (Ulwan; Erhamwilda, 2015).

Oversight responsibility of internal factors, among others:

1. Teach children early ethics ask permission to enter the room parents at three breaks

2. Avoiding a boy aged over 9 years of seeing women with jewelry or clothing that gives sexual rangasangan, and forbid a boy entering the room or the women's room

3. Boys and girls aged ten years should be separated his room, and his fellow boys should not sleep one blanket on the bed cypress, as well as fellow girls should not be a blanket and not to be a bed.

4. Children are taught ethics saw early on, with appropriate restrictions both in the child's age and adults seen by the older age and seeing boys and girls another.

5. Prevents children from watching images that stimulate, movies / soap opera that propagate freedom of association, in the event through television, mobile phones and other media.

6. Preventing child get along with others to enjoy nude pictures, porn magazines, stories obscene and erotic song that invites sexual stimulation. Educators always supervise children to know how to guide him. 
Responsibility Oversight external factors by way of supervision on factors within families and communities that will damage the morals of children, especially feature films, advertising, entertainment venues, bad neighborhood with prostitution overtly or covertly and fashion clothing that encourage girls show the contours of the body. Tight clothes for boys will give rise to sexual stimulation, women can have an impact on the behavior of flirtatious teasing. If early child used to bad environment at the time of entering the juvenile will be susceptible to sexual perversion.

\section{FINDINGS AND DISCUSSION}

This research was conducted with a qualitative approach. As a process that is trying to gain a better understanding of the complexities that exist in human interaction (Marshall \& Rossman: 1995). In this case the researchers wanted to get a picture of how cases of sexual violence occurred, ranging from the characteristics of the victim, the environment and the families of the victims, perpetrators and their environment. Data collecting technique is interview, documentation and observation studies. The data sources are those closest to the victims, child protection related government agencies, and NGOs and assist rehabiliatasi handles many cases of child abuse and domestic. Research site is in West Java. The data source is the early age of sexual violence victims, families and perpetrators. In addition, research is also equipped with the study of literature in the form of previous research reports, as well as articles related to sexual violence cases. Selection of research methods in accordance with the purpose of the study is to describe the state of cases of young children who sexually abused. Sampling was done by purposive, data analysis technique is inductive / qualitative, and the results further emphasize the significance.

Based on data collection techniques that have been described in the above, can be described the characteristics of cases of sexual abuse victims, perpetrators, environments, and the incidence of sexual violence early childhood in West Java described as follows. To maintain the good name of the victim and the family, then in the research report mentioned initials only.

1. Pr, Age 6 years initials $X$ was still in kindergarten.

$\operatorname{Pr} \mathrm{X}$ is the son of a wealthy family, who lived in an elite housing in one of the West Java town with mom and dad busy. Affairs needs children are assigned to the two drivers who alternately shuttle and a child at home more children are taken care of helpers. Events sexual violence is unknown parents, the incident came to light when a child complains of pain want to urinate, frequent body heat, and looks often anxious. At first the child does not want to tell you, but to be persuaded by aides close to the child then events unfold. It turns out the driver often treats 
children with indecent genitals, and the deed was done by both the driver alternately. The relationship between both parents and children are not close, because the parents more delight of the physical needs and luxuries, children rarely tell especially chatting with both parents. It happened when the pick-up school children, and carried in the car with persuading children and picking pubic children, and it happened repeatedly. The case was only reported to the Child Protection NGO, but the parent does not want the case to court extended for fear of damaging the good name of the family.

2. Boys case, early childhood classes $C, R$ initials age of 6 years

These children have a strong desire to always be near a girls, happy to follow the girls to the toilet, and want to help wash urinate. Besides this child like to talk raunchy, sexy, plump and addressing women from the body (which is not worth talking about small children as smooth, thigh). His mother and child labor night is ignored and much is left. Children stay with grandmother and step-grandfather who still has 2 kids that age are smaller. Step- grandfather and grandmother often scold, beat, abused, and $\mathrm{R}$ highly treated differently by the two small children of her grandmother. Her mother was rarely home. Even if the home is no concern for the child, except occasionally given money. Children do not have a certificate, the mother did not have a marriage certificate, the father of the child is not clear. If her mother was at home, the usual dress sexy, and looks much scar on his hand. Boys are often left free, play to the cafe, although no money, often watch in the cafe. Hygiene and food the child is not considered. Children to early childhood often do not bathe. Nowadays children often behave like girls, and if together boys become victims bullying. In the cafe is inevitable that children can be helped see pornographic videos watched by children are greater than he. Some girls are afraid of this child, because this child has a strong desire look at the girl opened her skirt. One student Pr always followed and when urinating, boys are picking the pubic child Pr. Genesis is known teacher, and finally the teacher always alert and keep an eye on the students Lk. Female student behavior due to fear of early childhood education is approached.

3. Case $\mathrm{C}$ girls initials

Age 5 years, the environment is very prone to get sexual abuse of his older brother were junior and often absent from school. His older brother was in the cafe often come to watch the other children. $\mathrm{C}$ are often left with her sister, and bathe $\mathrm{C}$ is his brother. C looks gloomy, do not want to tell, shabby appearance. $\mathrm{C}$ sometimes do not come to the kinder garden without bath. Besides his mother, who worked as a maid 
had many male friends, and mothers often intimate with the man, the child in the environment, it is not uncommon mother also sent the girl to her male friend. I do not care whether the child will be a victim of sexual violence by her male friend, or does not care if it will be treated indecent by men. Mother's behavior towards male friends have often warned by a neighbor. In this case the child can not be guaranteed to be protected from seeing her friends making out with her. In this case of sexual abuse could happen, but because the child was under pressure, he did not dare tell anyone.

4. S Girls

6 years of age who are victims of sexual violence of his own uncle, aged 23 , who works odd jobs, and like watching porn. The incidence of sexual violence initially unknown parents, because the child was persuaded, given pocket money, and often buy snacks. Actors do at home, while the other does not exist, children have often clocked, but the child did not report. The victim's parents know, after seeing his strange behavior, because of lingering in the bathroom, and caught masturbating, then persuaded to tell, the son often pornographic video from uncle hand phone, then coaxed do to a child hooked. Before the incident the parents rarely communicate with children, and children are often abandoned because the mother worked, and deemed safe by his uncle. The victim's mother demanded, but the victim's father asked resolved amicably. Which is very difficult to treat addiction is his daughter, and children rarely want to play with other children.

5. En, victims ages 2 years

Sexually abused from the age of 45 years neighbor. Victims are often left to the mother along with her brother who was in grade school. En often played with his brother in the house of the perpetrator, and the time of the incident, the brother who was told to return fetch pants, turned out to be the child's grandfather had been toying with the pubic. The return of a child crying in pain in his genitals, pain if you want to urinate, and the child has a fever heat. Genesis cannot be disclosed clearly because the child cannot tell. En from a family with many siblings. When the incident mother again went to the market, while the father works outside the city. Children every day just deposited at his brothers who had in elementary school. Condition of the house is very simple, and weak economic conditions. Many children were left, rarely to communicate.

6. $\mathrm{SN}$, female victims

Age 4 years, sexually abused from the perpetrator D 32 years, unemployment is the stepfather of the victim. The incidence of violence in the $\mathrm{SN}$ is not known exactly what happened. Sexual violence revealed, 
when the child complained of pubic pain, pain when urinate, fever, and when persuaded to tell the child to call D-plug cock striking, and has done repeatedly. Everyday children are often left with the mother's stepfather / actors, because mother every day to the market and work. Family economic conditions are weak, and the case was not followed up. Violence by the stepfather of the victim reported to police by neighbors, but the victim's mother did not want this incident followed up legally.

7. Girls, Su

Age 3 years, received the violence from the perpetrator S 60, that does not work, many stayed home. $\mathrm{S}$ is a close neighbor of the victim. The incidence of sexual violence is not known exactly, because children cannot tell in detail. Genesis caught since the child complained of pain in his genitals, and cry pain when urinating. Everyday children are usually with the mother, father work outside the city, and the child gets attention and supervision of the mother. The incidence of violence against children at all unexpected, time of occurrence mother would rush into the market, and children Leave to grandfather (the victims) are already considered your own. Victims from low-income families, and the acts of sexual violence only be resolved amicably, do not get legal action.

8. Brother and sister (Sister M Pr 3 years, younger brother J, male, 2 years) Victims of sexual violence from men 33 years, the owner of the rented house where children live, unemployment and many stay at home two children got mistreatment of these men, Girls complained of pain when urinating, and son man complained of pain in the rectum. Both children are often left alone in a rented house, because working mothers looking for wood, while his father worked in Jakarta, only go home once a week. Families living with an economy fit-fit so that the case does not proceed legally.

9. N, Girls

N 3 years of age are victims of sexual violence from male widowers age of 60 who is a market trader who lived in the same neighborhood with children. The neighborhood is a dense city environment/ market, with the average parents is a seller in the traditional market. In this environment for children to be left free play, and supervision of the child is very weak. The child's relationship with the perpetrator familiar, because children are often given cakes, candies, and the like, and victims often play together actors. The familiarity with the child easily persuaded grandfather. The incidence of sexual violence is unknown parents, and revealed after the child has an infection in his genitals, and when medically examined, is due to ill-treatment on the genitalia of children, such as held-hold or pierced by hand in a dirty state. After being 
persuaded to tell who was holding the child-holding it. It turns children are often lured and tricked his cock. The child's relationship with their parents are less familiar and warm not because mom and dad busy victims of trade in the market, children are often left to play freely, even the child tend unkempt clothes, as well as cleanliness.

10. Girl, initials IS

5.5 years of age is a child to 4 were the only women are victims of sexual violence from men who is a cousin of the victim. Perpetrators of grade VIII (junior high school), aged 14-15 years, who often see Internet porn video, and addictive game on line. Acts of sexual violence occurs when IS stay at his cousin and relationships coitus done perpetrator when the victim was sleeping, clocked up a torn hymen, bleeding and there were wounds on the genitals torn child. Supervision of the child's mother is weak, the victims are often left to play at will, even the victims are often left to play phone his mother, who was also a porn video. The victim's mother was also included women who are lonely because his father worked in New Guinea who lived with brother's first victim. Father amidst the optimism only go home at any time victim lived with his mother and two older brother. The case is being dealt with police, the victim's father demanded 75 million rupiah perpetrator's family, but was not granted the victim's family. Large families tend to side with the perpetrators, and blaming the victim's mother who complained to police.

11. Victims initials SA girls

Age of 4.5 years of sexual harassment from her cousins due invited her cousin was 7 years old who played the bride-groom and acting as a director who told 5 people her male cousins aged 4-6 years to have intercourse with her cousin were 4.5 year alternately. The victim was clocked repeatedly until the child feels pain. Genesis is known after the victim complained to her mother. In this case the child is not sent to the doctor, and this incident know the neighbor, then reported to the Chairman of the neighbor are forwarded to the NGO. Neighborhood where she lived is a solid neighborhood with housing conditions are cramped, there are no available rooms for the children, the children used to sleep together and the parents room in makeshift bulkhead.

Of the 11 cases were successfully obtained information as described above, it can be stated that the results of this study are consistent with previous studies, conducted overseas and in Indonesia. Victims of sexual abuse in early childhood can occur in the lower middle family, and also to the upper middle class family, but the victim more than the simple and poor families. This was triggered by the bad atmosphere, especially the home 
without a room divider between the room and the child's parents or bulkhead potluck. In this case the child is not protected to not see the nakedness of the parents and it is possible to observe the child (see or hear) the marital relationship that would interfere with his thoughts.

The role of mothers in protecting children not to become victims of sexual violence are very important, and the indifference of the mother towards the fulfillment of the needs of children, comfort the child inside and outside the home environment, as well as poor attention to the protection of children from various forms of violence become the main cause of sexual violence or sexual harassment in early childhood. This is evident from the cases of sexual violence were investigated turned out 10 of the 11 mothers are mothers who prioritizes work outside the home. On the other side of these case matters can also be stated that the role of the father as a protector of the family does not function properly. The cases occurred in children whose father is busy working though always go home, or his father rarely home, or a father who is irresponsible and leave the child away to her mother, divorced, and the worse is the child born as a result of an affair mother with boys -Eighteen masher without marriage.

In addition to the cases of sexual violence seen parental control against friends, place, and type per toys too weak, many children are left to grow on its own, and the incidence of sexual violence on children became known only after the child has a physical illness or abnormality in the development of socio-emotional. Subsequent findings related to the characteristics of perpetrators of sexual violence in early childhood, similar to previous findings, where the perpetrators of sexual violence are people who are around the child, the child is familiar with, often already believed parents to keep the child. This is evident in the cases described, that the perpetrators are: a driver, a neighbor, the owner of the rented, cousin, stepfather, uncle, older sibling, and the mother's male friend. This fact is in line with the proposed (Setiawan, 2014, p. 1).

Young offenders and children older than children who are victims once or even often watch porn via mobile phone, smartphone, watching participate in the cafe, or VCD. This fact is in line research Dr. Jennings Bryant (Andika, 2010, p. 32) Actors are adults or older are widowed, or have a wife who works outside the home, while the concerned unemployed and many at home. In addition, the adult male perpetrators of acts of sexual violence can also men who work, but his wife away and is concerned rarely go home, otherwise it is generally the workers have a smartphone, which can be facilitate to watch porn.

Judging from the mother's role in educating early childhood, seen in cases of victims of sexual violence is very less, even found to have the 
attitude and behavior of the mother becomes the cause of sexually abused children. Mothers who often use sexy clothes, making out with a man who is not her husband, while the child was in the neighborhood. What is seen the child would ruin his thinking, and could be the cause of sexual deviation in children. On the other hand looks at the cases of victims of sexual violence early age, the child's parents a communication link is less, because parents are busy working or there is also busy looking for fun for himself. This means that the relationship of parents of children with a warm atmosphere, democratic, full openness to educate children in the family did not materialize.

Thus through this research it was found that the lack of intensity of parent-child communication, has led to a lack of familiarity with the child's parents who make children rarely tell their parents at the same time demonstrate the weakness of psychological attachment between parents and children. Among the eleven cases were found, only one victim who is a child who is always with his mother, and the mother was always attentive to the child, and the incidence of sexual violence grandparents prediction neighbors outside the mother.

By looking at the lives of the families of child victims of sexual violence found that the fulfillment of physical and psychological needs of children are lacking, especially the need for security, love and be loved, appreciated and respected. Children are more satisfied his physical needs, and some even their physical needs for good nutrition, clean. Child victims of sexual violence, it is also largely neglected children.

\section{Implications for Education Efforts to Prevent Childhood of Sexual Abuse}

Education experts revealed early childhood education is basically the process of facilitating the development of the child in all aspects of his personality include: physical-motor aspects, moral-spiritual, language, cognitive, socio-emotional, and artistic creativity. It's a little different when viewed from an Islamic perspective sourced Revelation Allah which is then translated into attitudes and behavior in the Hadits of the Prophet Muhammad. The fundamental difference about the meaning of education stems from differing views on human nature, the potential it carries, his task on earth, and the ultimate goal of education. In educational theory formulated by experts based on empirical research in the field, more human is seen only in terms of physical, moral, religious, social, language, intelligence/ cognitive, art and creativity in life as individual beings, social creatures, nation and state, but is released from the individual's life vertically on the Most Creating the man himself is God Almighty, so that 
more of an educational focus hone a variety of children's intelligence to be able to live normal and healthy perspective on the environment where it is located.

On the other hand the Islamic nature of the child is a mandate from God to be educated to be able to perform its role as the representative of Allah on earth are born in a state of nature-sacred/ taubid and expected to return to God in a state of purity. All that is possible only if the child is educated to carry out the commands of Allah and Allah stop the ban. Thus Islamic education for young children is a conscious effort to help the growth and development potential that God has given to the child so that the child can become pious servants of Allah.

Allah has equipped every insane amount of potential in the form of: Physical and Rub containing Qalb and spirits. In Qalb there $A^{\prime}$ qal, liver, and Bashiroh / conscience, and humans are also given the passions that tend to pleasure, pleasure, greed, satisfaction, and encourages people to love the world. Allah through revelation also gives guidance on how to develop all the potential of the functioning of hearing, sight and hearts that are subject to the rules of Allah. This also implies that in educating children should be started on providing a good and proper stimulation on hearing, sight of children, and children in order to maintain the purity of heart is not subject to lust.

To that end, it is for educators Islam primarily the responsibility of parents and teachers to educate children is a heavy responsibility, because it prepares children mengahadi life of the world to survive the next world. The responsibility of Islamic education can be classified into seven main responsibilities include: (1) Education Faith, (2) Moral Education, (3) Education physical, (4) Educational ratio / reasoning, (5) Education psychosis, (6) Education social, (7) Sex Education (Ulwan, 1995, p. 164).

Thus the importance of sex education given by parents and teachers, so as to be aligned with other major education in Islamic education. Sex education become urgent because of the success of sex education can affect other educational success, and vice versa when sex education fails, then it could damage morale, interfere with the development of physical, beating lust ratio, having psychiatric disorders, and damaging social order. Further needs to be emphasized that the foundation of all kinds of Islamic education is education of faith.

Noting the discussion of victims of sexual abuse in early childhood, and the perpetrators of sexual violence, it can be proven that outbreaks of violence because of the weakness of the faith of the offender, so it is not able to control his desires encouragement. The world is the world of early childhood play, and play is corestone in helping the growth and development 
of early childhood, then sex education for early childhood ideal, not a series of messages or information that must be recorded children then used the child at the right time. Observing the various tips that have been suggested by the authors or researchers as presented in theory, it is appropriate to the material content characteristic cases of victims of sexual violence early age, but still need to be analyzed further approaches and methods of delivery. This is because children are not small adults who could talk just as adults, and children are also not an object that can be set as desired adults.

Taking into account the above discussion, and consider how Islam regulates the obligation of parents in educating children, pay attention to the characteristics of child victims of sexual violence, the characteristics of the offender, events and relationships the child's parents, then sex education for young children needs to be done with regard to the following :

1. Need to pre-marital guidance for the bride and groom, who also prepares educators to be able to perform its role when it entrusted the child, both as a husband and future father, as well as wives and mothers.

2. Need parenting for mothers with young children, on sex education for children, and improving the quality of mother child relationship especially build closeness in psychological and educational communication.

3. Sex education for young children is not enough to form any information that should be controlled by the child, but the approach is loving affection of a mother in the atmosphere of playing together will be more easily absorbed by children.

4. Mothers who have young children, need to prioritize attention to development of the child, and not compromising or letting them just for the sake of material gain.

5. The father still needs to get parenting, child protection and fulfillment as children's rights, which is not only the material but also the security, love affection and togetherness.

6. Sex education given by parents and teachers of early childhood education in the perspective of Islam beginning of exemplary parents, keeping the child's view by applying the limits of the relationship between the child with other children, separating place sleeping boy girl, room parents and children, foster shame, close the genitals, and develop harmonious communication in home stairs.

7. In Islam, the father was responsible for the family so that the obligation to give a living, protection- family protection from external parties who are not responsible, and the mother is responsible for the internal house, meeting the needs of children's nutrition, health and religious education 
and science. The mother can help dad make a living without neglecting his duties in educating children.

\section{CONCLUSION}

Based on the above discussion can be drawn several conclusions follow.

Victims of sexual abuse in children aged mostly more left to the parents, because the parents are busy working and communication links parents sorely lacking. The victim's father was rarely at home, or live far away and education of children more responsibility handed over to the mother. The attitude and behavior of the mother can be one of the triggers of sexual abuse in children. Perpetrators of sexual abuse are the people closest to the victim, and often have been trusted by parents. Actors and young adolescents tend to be caused by watching a porn video through social media. Sex education is urgent given, but it is not just the content of messages to be captured child. Sex education in early childhood should be given to the approach play and fun, through socioemotional relationships are warm and loving. The parents of early childhood, need to get a parenting prevention of child sexual abuse, and establish a warm relationship and open communication with children. Islam teaches sex education to keep the views of children, growing embarrassment, protect children, and separate beds, and cover the genitals. In this case needed to be conveyed through stories and play with the warm and cozy atmosphere.

\section{BIBLIOGRAPHY}

., (2008). Ensiklopedia Pelecehan Seksual terhadap Anak. Tersedia http://id.wikipedia.org/wiki/pelecehan_seksual_terhadap_anak\#cite_ note_medline2008-1.

(2015). Ensiklopedia. Tersedia online http://id.wikipedia. org/wiki/pelecehan_seksual_terhadap_anak.html. ., (2015). Mencegah Pelecehan Seksual pada Anak dengan Pendidikan Seks Dini. Tersedia online http://www.bayiku. org/tumbuh-kembang-anak/mencegah-pelecehan-seksual-padaanak.html. Diakses tanggal 20 Agustus 2015.

Andika, Alya., (2010). Ibu, Dari Mana Aku Lahir. Yogyakarta: Pustaka Grahatama.

Chalidah, Ellah Siti., (2005). Terapi Permainan bagi Anak yang Memerlukan Layanan Pendidikan Khusus. Jakarta: Depdikbud.

Cristiana, Elizabeth., (2008). Teknik Terapi Bermain pada Anak Usia Sekolah. Jurnal Pendidikan Dasar Vol 9 (1): 81-84. Surabaya: Universitas Negeri Surabaya. 
Dacey, John S \& Fiore, Lisa B., (2006). The safe Child Handbook (How to Proctect Your Family and Cope with Anciety in a Threat-Filled World). USA: JosseyBass.

Dewi, Endah Kumala., (2007). Aplikasi Play Therapy pada Kasus Kecemasan pada Anak. Prosiding Konferensi Nasional Stress Management dalam Berbagai Setting Kehidupan. Bandung: Ikatan Psikologi Klinis Indonesia.

Doni \& Mira., (2010). Kekerasan Seksual pada Anak. Newsletter Pulih Vol 15. Jakarta: Yayasan Pulih. Tersedia http://www.pulih.or. id/res/publikasi/newsletter. Diakses tanggal 17 Agustus 2015.

Erhamwilda., (2015). Hypotetical Model of Sex Education for Early Childhood with Adaptive Mediated Learning Experience. Proseeding International Conference of All Care for Children on Early Childhood Development. Surabaya.

Handadari, Phebe Illenia S. Woelan., (2011). Pemulihan Diri pada Korban Kekerasan Seksual. Jurnal Insan Vol 13 No. 02 Agustus 2011.

Surabaya: Fakultas Psikologi Universitas Airlangga.

Kriswanto, Clara., (2015). Seks, Es Krim, dan Kopi Susu. Parenting Jagadnita. Tersedia http://www.parenting.co. id/balita /cara + mengenalkan + seks + pada+balita. Diakses tanggal 22 Agustus 2015.

Krug, E., Linda D., James, Margaret., (2002). World Report on Violance and Health. World Health Organization. Geneva: Switzerland.

Levitan, R. D., N. A. Rector, Sheldon, T., \& Goering, P., (2003). Childhood Adversities Associated with Major Depression and/or Anxiety Disorders Incommunity Sample of Ontario Issues of Co-morbidity and Specifity. Journal Depression and Anxiety, 17, p. 34-42. Tersedia http://www.answers.com/topic/child-abuse.

Marshal, Catherine \& Gretchen B Rossman., (1995). Designing Qualitative Research. California: Sage Puplication Inc.

Maslihah, Sri., (2006). Kekerasan terhadap Anak: Model Transisional dan Dampak Jangka Panjang. Edukid: Jurnal Pendidikan Anak Usia Dini I Vol 1. Hal 25-33.

Maslihah, Sri., (2013). Play Therapy dalam Identifikasi Kasus Kekerasan Seksual terhadap Anak. Jurnal Penelitian Psikologi, Vol 4. No 01, hal 21-34. Bandung: Jurusan Psikologi, Universitas Pendidikan Indonesia.

Mc Anuitu, Richard D \& M. Michele Burnette., (2006). Sex and Sexuality: Sexual Deviation and Sexual Offenses. USA: Preager Publisher.

Nevid, J. S \& Rathus S A \& Greene, B. (1994). Abnormal Psychology in a Changing World, $2^{\text {nd }}$ ed. New Jersey: Prentice Hall Inc. 
Ranuh, I. G. N., (1999). Kelemahan dalam Pencatatan Kasus Child Abuse dan Cara Mengatasinya. Yogyakarta.

Roosa, M. W., Reinholtz C., Angelini P. J., (1999). The Relation of Child Sexual Abuse and Depression in Young Women: Comparisons Across Four Ethnic Group. Journal Abnormal Child Psychology 27 (1) : 6575.

Selter, Anna., (1988). Treating Child Sex Offenders and Victims: A Practical Guide. USA: Sage Publication.

Setyawan, D., (2014). Kasus Bullying dan Pendidikan Karakter. Tersedia http://www.kpai.go,id/berita/kpai-kasus-bullying-dan-pendidikankarakter.html

Sue, D., Sue, S., (1994). Understanding Abnormal Behavior, $4^{\text {th }}$ ed. Boston: Houghton Mifflin Company.

Tower , Cyntia Crosson. (2002). Understanding Child Abuse and Neglect. Boston: Allyn \& Bacon.

Ulwan, Nashih., (2007). Pendidikan Anak dalam Islam Jilid 1, 2. Jakarta: Pustaka Amani.

Ulwan, Nasih., (1995). Pendidikan Anak Islam. Jakarta: Pustaka Amini. 